Clinical Experience,

\title{
Clinical Outcome of Neurologic Patients Given Free Human Intravenous Immunoglobulin through the Department Of Health Medical Assistance Fund Program at the Philippine General Hospital
}

\author{
Roemer D. Tanghal, MD', Scarlett Mia S. Tabuñar, MD, MHA, FPCEM² \\ ${ }^{1}$ Department of Emergency Medicine, Philippine General Hospital, University of the \\ Philippines-Manila \\ ${ }^{2}$ Department of Emergency Medicine, College of Medicine/Philippine General Hospital, University of the \\ Philippines-Manila \\ Email Address: sstabunar@up.edu.ph
}

\begin{abstract}
:
Health outcome assessment of expensive drugs eg. IVIG which is the treatment of choice for various immune-mediated diseases of the central and peripheral nervous system is essential in the efficient management of limited funds of government hospitals. The objective of this pilot prospective medical record review is to determine the clinical outcome of neurologic patients given free IVIG through the Department of Health Medical Assistance Fund Program (DOH-MAFP) to assist indigent patients in their medical needs from 01 January- 30 June 2019 at the University of the Philippines-Philippine General Hospital (UP-PGH). A total of 70 patients received IVIG for various illnesses; only 7 were for neurologic indications namely Guillain-Barre Syndrome, Myasthenia Gravis, anti-NMDA receptor encephalitis and chronic inflammatory demyelinating polyneuropathy. Majority of free IVIG beneficiaries were female, of pediatric age group and classified by the medical social service (MSS) as class D. The average amount spent is Php 163,592.72( USD 3,192.67) for all the diseases and the overall average hospital stay $=21.14$ days. However, patients with Guillain-Barre Syndrome had an average hospital stay of 6.5 days which is the shortest recorded. In conclusion, all patients given free IVIG are discharged improved whether it is used as a primary or definitive treatment or as an adjunct therapy with no mortality or hospital complication. The accrued cost of treatment is lower compared to other studies. It is therefore recommended to continue the free provision of IVIG from DOH-MAFP to indigent PGH patients and sustain monitoring of clinical outcomes of future utilization of free IVIG.
\end{abstract}

Keywords: Human Intravenous Immunoglobulin; DOH-MAFP; Neurologic Patients

\section{Interoduction:}

Since health care resources are fixed and predetermined, it is imperative for hospital management to use them rationally and to consider the economic consequences of different medical interventions. One of the costly therapeutic interventions is the use of the 4th generation Intravenous Immugolublin (IVIG) by various clinical specialties mainly neurology, hematology, immunology, nephrology, rheumatology and dermatology (Jolles, Sewell, \& Misbah, 2005).
Although IVIG is known to be more expensive compared to the conventional treatment eg. Corticosteroids and plasma exchange in autoimmune neurologic disorders, it is now used as the first-line therapy for Guillain- Barre syndrome (GBS), chronic inflammatory demyelinating Polyradiculoneuropathy (CIDP), multifocal motor neuropathy (MMN) and dermatomyositis (DM) (Elovaara, et al., 2012).

The estimated incidence of GBS is between 1.11.8/100,000/year (mcgrogan A, 2009), and a metaanalysis shows that there is an increment increase 
of $20 \%$ for every 10 - year rise in age (Sejvar, 2011).

In the Philippines, the increasing IVIG usage has also expanded its market size from USD 4.5 million in 2006 to a projected USD 16 million by 2022 with a compounded annual growth rate of 7.1\% based on the 2017 Market Research Report on IVIG (Dans, 2017). The report also cites that, locally, majority of IVIG has been purchased and used for immunodeficiency, autoimmune diseases and acute infection. In the past years, it has been very difficult to procure the needed IVIG due to its exorbitant cost even if it is established that it is part of the primary management and considered as an adjunct medical therapy for most of autoimmune and acute inflammatory neurologic disorders. Since the establishment of DOH-MAFP at PGH in 2014 , the availability of free IVIG is made possible through this funding program.

The hospital is able to acquire Immunoglobulin Normal Human $5 \%$ at $50 \mathrm{mg} / \mathrm{ml}$ preparation for Php8,399.00 (USD 163.91) and $100 \mathrm{mg} / \mathrm{ml}$ preparation at Php17,500.00 (USD 341.53). The frequency of administration depends on the disease entity, mostly given twice a day for five days in cases of peripheral neuropathy resulting to Php175,000 (USD 3,415.300) expense per patient in total. Due to the prohibitive price of this medication, this preliminary study aims to determine the clinical outcome of patients given free IVIG through the Department of Health Medical Assistance Fund Program (DOH-MAFP) and provide a baseline data of the its utilization at UP-PGH.

\section{Methods:}

A prospective, cross-sectional study was conducted through medical record review for a six-month period from 01 January to 30 June 2019 at the Adult and Pediatric Neurology Service Wards of UP-PGH, which is a 1,500 bed-hospital serving a population of 600,000 patients per year. Data gathered from the medical charts of free IVIG beneficiaries included: initial and final discharge diagnoses, medical social service (MSS) classification, average amount spent for IVIG, total length of hospital stay, any hospital complication and final disposition or clinical outcome. Ethics approval from UP- Manila-Review Ethics Board's (UPM-REB 2019-170-01) was secured prior to study implementation. All collected data were recorded in Microsoft Excel and analyzed using STATA V12. Data processing included computation of frequencies, percentages and cross- tabulations

\section{Results:}

There were 70 patients who were given free IVIG through DOH-MAFP during the 6-month study period but only 7 cases were for neurologic indications (Figure 1).

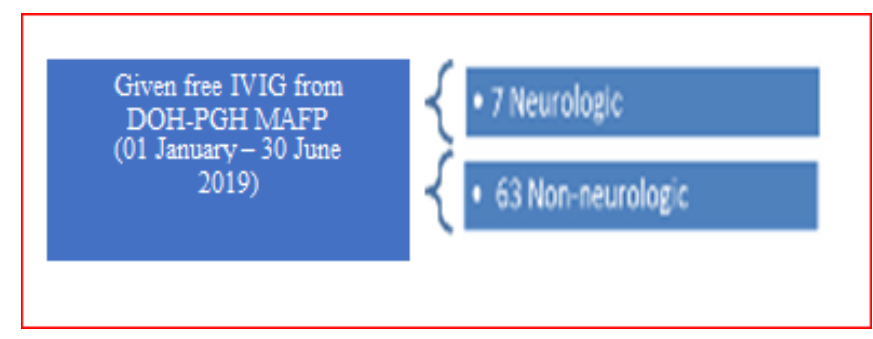

Figure 1.Classification of patients provided with free IVIG from DOH-MAFP

The majority of the seven neurologic patients were female, less than 18 years old, classified under medical social service class $\mathrm{D}$ and had mean hospitalization of 21.14 days (Table 1 ).

Table 1. Sociodemographic profile of neurologic patients given free IVIG $(\mathrm{N}=7)$

\begin{tabular}{lrc}
\hline Data & & $\mathrm{n}(\%)$ \\
\hline \multirow{2}{*}{ Age } & & \\
& Pediatric ( $<18$ years old) & $4(57 \%)$ \\
Sex & Adult $(\geq 18$ years old) & $3(43 \%)$ \\
& & \\
MSS Classification & Male & $1(14 \%)$ \\
& Female & $6(86 \%)$ \\
& Class A & 0 \\
& Class B & 0 \\
Mean_Length_of Hospitalization_days) & Class C & $1(14 \%)$ \\
\hline
\end{tabular}

Among the non-neurologic conditions (Table 2) which received IVIG, most were hematologic cases with diagnoses of aplastic anemia and immune thrombocytopenic purpura (ITP); followed by patients with malignancies such as mixed germ cell tumor, Wilm's tumor and retinoblastima. It was also given to infectious, gastric, cardiac, hepatic, trauma, dermatologic and urologic conditions. 
Roemer D. Tanghal et all. / Clinical Outcome of Neurologic Patients Given Free Human Intravenous Immunoglobulin through the Department Of Health Medical Assistance Fund Program at the Philippine General Hospital

Table 2. Breakdown of Non-neurologic cases given free IVIG

\begin{tabular}{|ll|} 
Case Classification & $\begin{array}{l}\text { Number of } \\
\text { patient }\end{array}$ \\
\cline { 2 - 2 } Hematology & 18 \\
Oncology & 13 \\
Infectious & 10 \\
Gastroenterology & 8 \\
Cardiology & 5 \\
Hepatology & 3 \\
Trauma & 2 \\
Dermatology & 3 \\
Urology & 1 \\
\hline
\end{tabular}

Most of the neurologic patients who received free IVIG had an initial diagnosis of Guillain-Barre Syndrome; other diseases that used the same treatment modality included myasthenia

Ravis, chronic inflammatory demyelinating polyneuropathy and anti- N-methyl D-aspartate (NMDA) receptor encephalitis (Table 3).

Table 3. Summary of neurologic initial and discharge diagnosis $(\mathrm{N}=7)$

\begin{tabular}{lcc}
\hline Disease & $\begin{array}{c}\text { Initial } \\
\text { Diagnosis } \\
\mathbf{n ( \% )}\end{array}$ & $\begin{array}{c}\text { Final/Discharge } \\
\text { Diagnosis } \\
\mathbf{n ( \% )}\end{array}$ \\
\cline { 2 - 2 } $\begin{array}{l}\text { Guillain-Barre Syndrome } \\
\text { Myasthenia Gravis }\end{array}$ & $2(43 \%)$ & $2(28.5 \%)$ \\
Chronic Inflammatory & 0 & $2(28.5 \%)$ \\
$\begin{array}{l}\text { Demyelinating Polyneuropathy } \\
\text { Others (anti-NMDA receptor }\end{array}$ & $2(28.5 \%)$ & $1(14.5 \%)$ \\
encephalitis & & $2(28.5 \%)$ \\
\hline
\end{tabular}

Majority of these patients, both pediatric and adult, received the free IVIG for GBS $(n=2)$ and Myasthenia Gravis $(n=2)$ during the second quarter of the year, April to June 2019 (Figure 1).

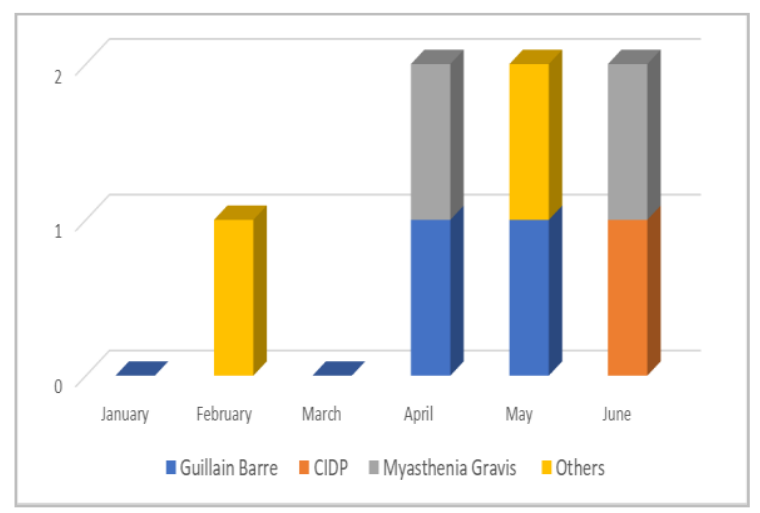

Figure 1. Total number of patients given free IVIG per month from Jan-June 2019 (N=7)
Table 4 below details the total expenditure per month per department of patients given free IVIG under the DOH-PGH MAFP during the six-month period. The total cost was Php1,145,149.00 (USD $22,348.73)^{*}$, for which more than half $(57.9 \%)$ was used for adult patients and the average expense per patient was Php163,592.72 (USD 3,192.67). The expenditure ranges from Php 188,750.00 (USD $3,683.64$ ) to as high as Php 475,000 (USD 9,270.10) per month, with the highest spending during the month of June.

Table 4. Breakdown of expenditure per month of IVIG from January to June 2019. Pediatric vs Adult Neurology

\begin{tabular}{|c|c|c|c|}
\hline Month & $\begin{array}{c}\text { Pediatric Neurology } \\
\text { in } \mathrm{Php} \text { (USD)* } \\
n=4\end{array}$ & $\begin{array}{l}\text { Adult Neurology, } \\
\text { in Php (USD)* } \\
n=3\end{array}$ & $\begin{array}{l}\text { Total } \\
\text { in } \mathrm{Php} \text { (USD)* }\end{array}$ \\
\hline January & 0 & 0 & 0 \\
\hline February & $\begin{array}{c}188,750 \\
\text { (USD } 3,683.64 \text { ) }\end{array}$ & 0 & $\begin{array}{c}188,750 \\
\text { (USD } 3,683.64 \text { ) }\end{array}$ \\
\hline March & 0 & 0 & 0 \\
\hline April & $\begin{array}{c}91,524 \\
\text { (USD1,786.18) }\end{array}$ & $\begin{array}{c}178,125 \\
\text { (USD3,476.29) }\end{array}$ & $\begin{array}{c}269,649 \\
\text { (USD } 5,262.47 \text { ) }\end{array}$ \\
\hline May & $\begin{array}{c}23,750 \\
\text { (USD463.50) }\end{array}$ & $\begin{array}{c}188,000 \\
\text { (USD3,669) }\end{array}$ & $\begin{array}{c}211,750 \\
\text { (USD4,132.51) }\end{array}$ \\
\hline June & $\begin{array}{c}178,125 \\
\text { (USD } 3,476.28 \text { ) }\end{array}$ & 296,875 & 475,000 \\
\hline Total & $\begin{array}{c}482,149 \\
\text { (USD9,409.62) } \\
\sim 42.1 \% \\
\end{array}$ & $\begin{array}{c}663,000 \\
\text { (USD12,939.11) } \\
\sim 57,9 \%\end{array}$ & $\begin{array}{c}1,145,149 \\
(\mathrm{USD} 22,348.73)\end{array}$ \\
\hline
\end{tabular}

The largest amount (Php 296, 875.00 USD 5,793.81) was spent in an adult Guillain-Barre Syndrome patient, and the least was given to a pediatric anti-NMDA receptor encephalitis case at Php23,750.00 USD 463.50 (Table 4). By far, GBS had the greatest share of the IVIG expenditure at Php 388,399.00 (USD 7,580) as shown in Table 5 below.

Table 5. Expenditure per disease in $\mathrm{Php}(\mathrm{N}=7)$

\begin{tabular}{|c|c|c|c|}
\hline Disease & $\begin{array}{c}\text { Pediatric Neurology } \\
\text { in Php (USD) } \\
n=4\end{array}$ & $\begin{array}{l}\text { Adult Neurology } \\
\text { in Php (USD) } \\
n=3\end{array}$ & $\begin{array}{l}\text { Total } \\
\text { in Php (USD) }\end{array}$ \\
\hline $\begin{array}{l}\text { Gullar-Barte } \\
\text { Syndrome }\end{array}$ & $\begin{array}{c}91,524 \\
\text { (USD } 1,786.18 \text { ) }\end{array}$ & $\begin{array}{c}296,875 \\
\text { (USD 5,793.81) }\end{array}$ & $\begin{array}{c}388,399 \\
\text { (USD 7,580) }\end{array}$ \\
\hline $\begin{array}{l}\text { Myas the nia } \\
\text { Gravis }\end{array}$ & $\begin{array}{c}178,125 \\
(\mathrm{USD} 3,476.28)\end{array}$ & $\begin{array}{c}178,125 \\
(\mathrm{USD} 3,476.28)\end{array}$ & $\begin{array}{c}356,250 \\
\text { (USD 6,952.58) }\end{array}$ \\
\hline $\begin{array}{l}\text { Chronic } \\
\text { Inflammatory } \\
\text { Demyelinating } \\
\text { Polyn eu ro pathy }\end{array}$ & 0 & $\begin{array}{c}188,000 \\
\text { (USD 3,669) }\end{array}$ & $\begin{array}{c}188,000 \\
\text { (USD 3,669) }\end{array}$ \\
\hline $\begin{array}{l}\text { Others } \\
\text { (anti-NMDA } \\
\text { receptor } \\
\text { encey ha litis }\end{array}$ & $\begin{array}{c}212,500 \\
\text { (USD 4,147) }\end{array}$ & 0 & $\begin{array}{c}212,500 \\
\text { (USD 4,147) }\end{array}$ \\
\hline Total & $\begin{array}{c}482,149 \\
\text { (USD 9,409.62) }\end{array}$ & $\begin{array}{c}663,000 \\
\text { (USD } 12,939,11 \text { ) }\end{array}$ & $\begin{array}{c}1,145,149 \\
\text { (USD 22,348.73) }\end{array}$ \\
\hline
\end{tabular}



through the Department Of Health Medical Assistance Fund Program at the Philippine General Hospital

The overall average length of hospital stay (ALOS) is 21.14 days, with adult chronic inflammatory demyelinating polyneuropathy (CIDP) having the longest LOS of 65 days and adult GBS having the shortest at 5 days. The adult patients given free IVIG had longer ALOS= 26.33 days compared to the pediatric patients which on the average stayed for 17.25 days. Details are shown in the table 6 below.

Table 6. Total and average length of hospital stay per disease $(\mathrm{N}=7)$

\begin{tabular}{|c|c|c|c|}
\hline Disease & $\begin{array}{c}\text { Pediatric Neurology } \\
\text { Total LOS (days) } \\
\text { n=4 }\end{array}$ & $\begin{array}{c}\text { Adult Neurology } \\
\text { Total LOS (days) } \\
\text { n=3 }\end{array}$ & $\begin{array}{l}\text { Average LOS } \\
\text { (days) }\end{array}$ \\
\hline $\begin{array}{l}\text { Gullad-Barte } \\
\text { Syndrome }\end{array}$ & 8 & 5 & 6.5 \\
\hline $\begin{array}{l}\text { Nyas the ria } \\
\text { Gravis }\end{array}$ & 9 & 9 & 9 \\
\hline $\begin{array}{l}\text { Chronic } \\
\text { Inflammatory } \\
\text { Demyelinating } \\
\text { Polyn eu ro pathy }\end{array}$ & 0 & 65 & 65 \\
\hline $\begin{array}{l}\text { Others (anti- } \\
\text { NMDA } \\
\text { receptor } \\
\text { encep ha litis }\end{array}$ & $\begin{array}{c}52 \\
(n=2)\end{array}$ & 0 & 26 \\
\hline $\begin{array}{r}\text { Average LOS } \\
\text { (days) }\end{array}$ & 17.25 & 26.33 & 21.14 \\
\hline
\end{tabular}

Finally, all 7 neurologic patients given free IVIG through the DOH MAFP were discharged improved with no hospital complications recorded. For the non-neurologic conditions, 61 patients were also discharged well, only one patient died, a 9- month old male with $16.75 \%$ total body surface scald burn and another 6-day old male with sepsis went home per relative's request.

\section{Discussion:}

Since the procurement of UP-PGH of IVIG through the DOH- MAFP, there has been a noted increase in its utilization, both as the definitive therapeutic intervention and as an adjunct therapy for neurologic and autoimmune disorders. The wide-range uses of IVIG as an immunomodulatory agent with hematologic, (eg. Immune thrombocytopenic purpura and aplastic anemia) oncologic, (eg. mixed germ cell tumor, Wilm's tumor), dermatologic (ex Kawasaki disease, Toxic Epidermal Necrolysis), renal and rheumatologic cases have long been established by several studies (Hughes, et al., 2009; Jolles, Sewell, \& Misbah, 2005). But in the last 3 decades, a number of randomized controlled trials have also shown its efficacy in various neuroimmunological disorders such as GBS, multifocal motor neuropathy (MMN), chronic inflammatory demyelinating polyneuropathy (CIDP), myasthenia gravis, dermatomyositis and stiff-person syndrome (Stangel, 2008; Hartung, et al., 2009; Hughes , et al., 2009). Locally, the intravenous immunoglobulins are also now being used for the same conditions but are precluded by its prohibitive cost. In the current study, a total of 70 patients availed of the free IVIG through DOHMAFP for different indications which are markedly higher compared to the single recorded IVIG use for an allergology patient in 2013 (Institutional research, planning and development, 2013). This huge jump in IVIG consumption, in a manner confirms the 2017 forecast report of compounded annual growth rate of its market size (Dans, 2017).

The seven pediatric and adult neurologic patients provided with free IVIG comprised of Guillain Barre Syndrome (28.5\%), Myasthenia Gravis (28.5\%), anti-NMDA receptor encephalitis $(28.5 \%)$ and CIDP (14.5\%), all of which are chronic and autoimmune in nature. Most of the recipients are female, below 18 years of age, belonging to MSS class D or those patients admitted to the charity ward/bed, with no permanent means of living and whose income ranges from 0 to $\mathrm{Php} 10,504.00$ per month (Colmenares \& Zarate, 2013). Bersales in 2016 reported that a Filipino family with an estimated income of Php 22,000.00 per month has an average savings of $\sim$ Php 52,000.00 per year (Bersales, 2016). Thus, for an ordinary Filipino family who may require this kind of treatment modality, the IVIG cost is not within their reach. The only recourse for most of the underprivileged and indigent patients is to avail of the free services and assistance from tertiary government hospitals such as the DOH-MAFP.

All patient beneficiaries used IVIG in different amounts based on their weight hence the per patient cost depended on the doses that were used. Overall, the average amount spent for patients with neurologic disorders is $\mathrm{Php} \mathrm{163,592.72.} \mathrm{In} \mathrm{a}$ similar study using IVIG for myasthenia gravis treatment, the total cost quoted for the therapy ranges from USD 5,000- 10,000 depending on the patient's weight and number of infusions per course (Hayes Inc, 2016). This is much higher to the reported average cost of $\mathrm{Php} 178,125.00$ ( USD 3,500) for myasthenia gravis patients in UP-PGH in this preliminary review.

One of the known benefits derived from IVIG administration is the resulting shorter hospital stay 
(Coll-Cantí , et al., 2009). This current chart review shows that the average length of stay of patients given free IVIG is 21.14 days, with Guillain Barre Syndrome having the shortest average LOS of 6.5 days which is consistent to the findings of Del Rosso et al, that patients with GBS who were treated with IVIG has a shorter hospital stay compared those patients who did not receive the same immunomodulatory agent.

All neurologic patients given free IVIG were discharged from the hospital improved with no complications regardless of the diagnosis or whether it is used as a primary or definitive treatment or as an adjunct therapy.

\section{Conclusion:}

The provision of free IVIG through DOH-MAFP in the management of neurologic patients in both pediatric and adult group at the UP-PGH yielded beneficial outcomes as all recipients were discharged in improved condition with shorter length of stay and no other complications. It is therefore recommended that the DOH-MAFP continue providing free IVIG for the deserving patients of Philippine General Hospital as it is shown in the present study that it resulted to satisfactory clinical outcomes. However, it is still also suggested to continue diligent and cautious monitoring of its utilization because the number of patients included in this pilot review is very small and limited to a short period of time. Nonetheless, these initial results are encouraging enough to continue giving free IVIG to modulate the course of disorders with putative autoimmune pathophysiology. These findings serve as a baseline data for the usage of free IVIG and are limited to neurologic patients. Further investigations should be undertaken both for neurologic and non-neurologic disorders for which IVIG has recognized efficacy from Class I evidence, this in the future will definitely assist in the efficient allocation of hospital resources and funding. Acknowledgement: This research paper was supported by the UP-PGH Research Grant 2019.

\section{References:}

[1] Bersales, L. G. (2016). Average Family Income in 2015 is estimated at 22 Thousand Pesos Monthly. Philippine Statistics Authority.

[2] Colmenares, N. J., \& Zarate, C. (2013). Resolution Directing the Committe on Health to Conduct an Inquiry on the Increased Rates of Services Charges by the Philippine General Hospital to Class D/Indigent Patients. Quezon City: Republic of the Philippines - House of Representatives.

[3] Dans, R. (2017). 2017-2022 Philippines Intravenous Immunoglobulin Market Report (Status and Outlook). LPI.

[4] Del Rosso, J., Coll-Cantí, J., Alvarez-Ramo, R., Dorado, L., Guerrero, C., Serichol, M., Martinez, E. (2009, May). Guillain-Barre syndrome and IVIg: does early initiation of treatment influence the mean hospital stay? Neurologia, 24(4), 217-219.

[5] Elovaara, I., Apostolski, S., van Doorn, P., Gilhus, N., Hietaharju, A., Honkaniemi, J., Udd, B. (2012). Intravenous immunoglobulin in the treatment of neurological diseases. In N. Gilhus, M. P. Barnes, \& M. Brainin, European Handbook of Neurological Management: Volume 2, Second Edition. Edited by (Vol. 2, pp. 111-127). Blackwell Publishing Ltd.

[6] Hartung, H.-P., Mouthon, L., Ahmed, R., Jordan, S., Laupland, K., \& Jolles, S. (2009, Aug 20). Clinical applications of intravenous immunoglobulins (IVIg) -beyond immunodeficiencies and neurology. Clinical and Experimental Immunology, 158(Suppl.1), 23-33.

[7] Hayes Inc. (2016). Intravenous immunoglobulin for the treatment of myasthenia gravis. National Insittute for Health Research. Lansdale, PA, USA. Retrieved November 2019

[8] Hughes, R., Dalakas, M., Cornblath, D., Latov, N., Weksler, M., \& Relkin, N. (2009, Aug 20). Clinical applications of intravenous immunoglobulins in neurology. Clinical and Experimental Immunology, 158(Supp 1), 3442 .

[9] Institutional research, planning and development. (2013). Philippine General Hospital Facts and Figures 2013. Manila: Philippine General Hospital.

[10] Jolles, S., Sewell, W., \& Misbah, S. (2005, October). Clinical uses of Intravenous 
Roemer D. Tanghal et all. / Clinical Outcome of Neurologic Patients Given Free Human Intravenous Immunoglobulin through the Department Of Health Medical Assistance Fund Program at the Philippine General Hospital

immunoglobulin. Clinical and Experimental

Immunology, $\quad 142(1)$, 111 . doi:10.1111/j.1365-2249.2005.02834.x

[11] McGrogan A, M. G. (2009). The epidemiology of Guillain- Barré Syndrome worldwide. Neuroepidemiology, 32(2), 150163. doi:10.1159/000184748

[12] Sejvar, J. B. (2011). Population Incidence of Guillain-Barré Syndrome: A Systematic Review and Meta-analysis. Neuroepidemiology, 36(2), 123-133. doi: $10.1159 / 000324710$

[13] Stangel, M. (2008). New advances in the treatment of neurological diseases using high dose intravenous immunoglobulins. Therapeutics advances in neurological disorders, 1(2), 115-124. doi:10.1177/1756285608095747 